J. Perinat. Med. Evaluation of the feto-placental function by means of intraamniotic 7 (1979) 149 \title{
administration of dehydroepiandrosterone-sulphate
}

\author{
S. Dell'Acqua, E. Parlati, A. Lucisano, G. Plotti, F. Serri, A. Bompiani
}

Università Cattolica del Sacro Cuore, Rome, Italy

\section{Introduction}

The estriol or estrogens determination in maternal urine is a well established test of feto-placental function, extensively used for the diagnosis of pregnancy at risk.

It is know that the most important precursor of estriol (representing $90 \%$ of the total estrogens excreted in maternal urines) is fetal 16-hydroxylated dehydroepiandrosterone-sulphate.

In the last trimester of gestation about $80-90 \%$ of the estriol precursors are produced by the fetal adrenals and about $10-20 \%$ by the maternal ones; about $50 \%$ of the precursors of estrone and $17 \beta$ estradiol are produced by the fetus and about $50 \%$ by the mother (for a review, see DiczFalusY [3]).

The predictive value of urinary estriol or estrogens determinations concerning fetal outcome in different pathological conditions seems to be only about $70 \%$ correct [7].

In recent years several investigators have proposed the use of dynamic tests, which could complement and improve the diagnostic possibilities provided by the simple estriol or estrogens assay, also in terms of long-term prognosis of fetal'conditions [8].

The conversion of DHEA-S into estrogens takes place mainly in the placenta [3].

Such tests are based upon supplying a large amount of DHEA-S to the placenta, to evaluate its steroidmetabolizing capacity under load conditions.
Curriculum vitae

SERGIO DELL'ACQUA born 1936, graduated from the University of Milan (Italy) in 1962. Training in obstetrics and gynecology at the University of Milan. Guest scientist from $\mathrm{Fe}$ bruary 1964 to October 1965 at the Reproductive Endocrinology Research Unit, Karolinska sinkhuset, Stockholm, as a holder of a special Ford Foundation Fellowship in Reproductive

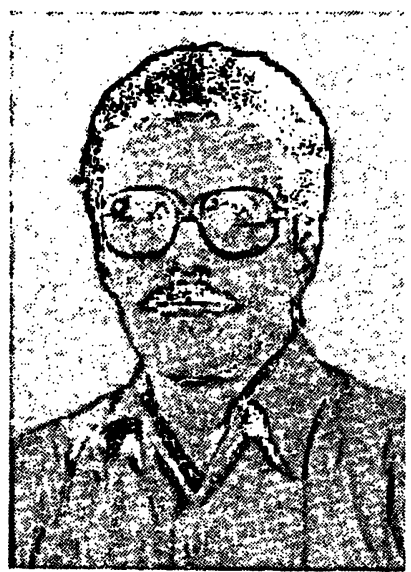

Endocrinology. At present associate professor of $O b$ stet. Gynecol. Endocrinology, Università Cattolica del Sacro Cuore, Rome, Italy. Research in the field of human reproductive endocrinology, both in pregnant and in non pregnant women, especially in the steroids synthesis and metabolism in the ovary and in the foeto-placental unit.

The purpose of the present investigation was to establish the clinical utility of a dynamic test based on the administration of DHEA-S into the amniotic cavity.

\section{Material and method}

The test was performed in 12 cases of normal pregnancies, ranging from the 33 th to the 37 th week of gestation and in 33 cases of pathological pregnancies (10 intrauterine fetal growth retardation, 3 diabetes, 3 cardiopaty, 4 chronic hyper- 
tension, 2 toxemia, 3 idiopathic jaundice of pregnancy, 2 anaemia, $2 \mathrm{Rh}$-isoimmunisation, 2 fetal anencephalia, 1 myomectomy in pregnancy, 1 plastic unification of a double uterus before pregnancy) ranging from the 32 th to the 38 th week of gestation.

Two hundred mg of DHEA-S were rapidly injected into the amniotic cavity, after localization of the placental area using $\mathbb{I N}^{113}$ [12].

The increment of maternal urinary excretion of total estrogens over the $24 \mathrm{hrs}$ following the DHEA-S injection was assessed as the percentage of the mean of the two $24 \mathrm{hr}$ excretion values before DHEA-S administration.

By means of urinary assays performed every 2-4 hrs, it was established that the increase in urinary estrogens starts 6-8 hrs after DHEA-S administration (Fig. 3).

For the above reason it seems more convenient to begin the evaluation of the increment $8 \mathrm{hrs}$ after DHEA-S injection.

As daily urines collection in our department starts at 6 a.m., the intraamniotic injection of DHEA-S was given to 10 p.m. on the previous day.

Total urinary estrogens were measured according to the BROWN, BEISHER and SMITH [1] method, modified by MENINI and BoMPIANI [11].

DHEA-S was kindly supplied by Roche, Basel.

\section{Results}

Fig. 1 illustrates the profiles of total urinary estrogens excretion in 8 cases of normal pregnancies before and after intraamniotic administration of DHEA-S.

In all the 12 cases examined, an increment of total urinary estrogens exceeding $100 \%$ was obtained, with an average of $147.6 \% \pm 46.6$ S.D. (Tab. I).

Fig. 2 illustrates the profiles of total urinary estrogens excretion in 8 cases of pathological pregnancies.

In 28 out of 33 cases of pathological pregnancies examined the increment never reached $100 \%$ with an áverage of $48.6 \% \pm 19.2$ S.D. (Tabs..II, III).

It is interesting to note that in normal pregnancies the increase is contained over the first $24 \mathrm{hr}$ period, but persists in the following days:
Fig. 3 shows two profiles of urinary assays of total estrogens, performed every $4 \mathrm{hrs,} \mathrm{in} \mathrm{two} \mathrm{cases,} \mathrm{one}$ normal and one pathological. The two profiles clearly exhibit a different increment curve. Furthermore no significant increase in the excretion is found to occur in either profile over the first $8 \mathrm{hrs}$ period following DHEA-S administration.

Tabs. I-IV show a comparison of the results obtained using the intraamniotic DHEA-S test with the values of the daily urinary estrogens determined serially during the last trimester of gestation.

Tab. I illustrates the 12 normal cases, in which the urinary estrogens values were all within the normal range and the increase after DHEA-S administration always exceeded $100 \%$.

In this group all the deliveries were normal and the newborn weight and the APGAR score were within normal limits.

Tab. II shows 4 pathological pregnancies, in which the urinary estrogens values were below the normal range and the increase after DHEA-S administration never reached $100 \%$.

Two of these patients were submitted to cesarian section for fetal distress and the newborns were underweight.

Tab. III illustrates 24 pathological cases, in which the urinary estrogens values were within the normal range or at border line, but the increment after DHEA-S administration never reached $100 \%$. In this group we can observe 6 cesarian sections for fetal distress and one in utero fetal death.

In Tab. IV 5 pathological cases have been collected, in which the urinary estrogens values were below the normal range, but the increment after DHEA-S administration always exceeded $100 \%$. We have no explanation for the first case, where the abnormal increment could be due to a technical error, but in the other four cases one newborn was mongoloid, the second was affected with congenital nanism and the other two were anencephalic.

\section{Discussion}

Intraamniotic injection of DHEA-S rather than maternal intravenous administration was favored, assuming that a higher concentration of the steroid would thus reach the feto-placental unit. 

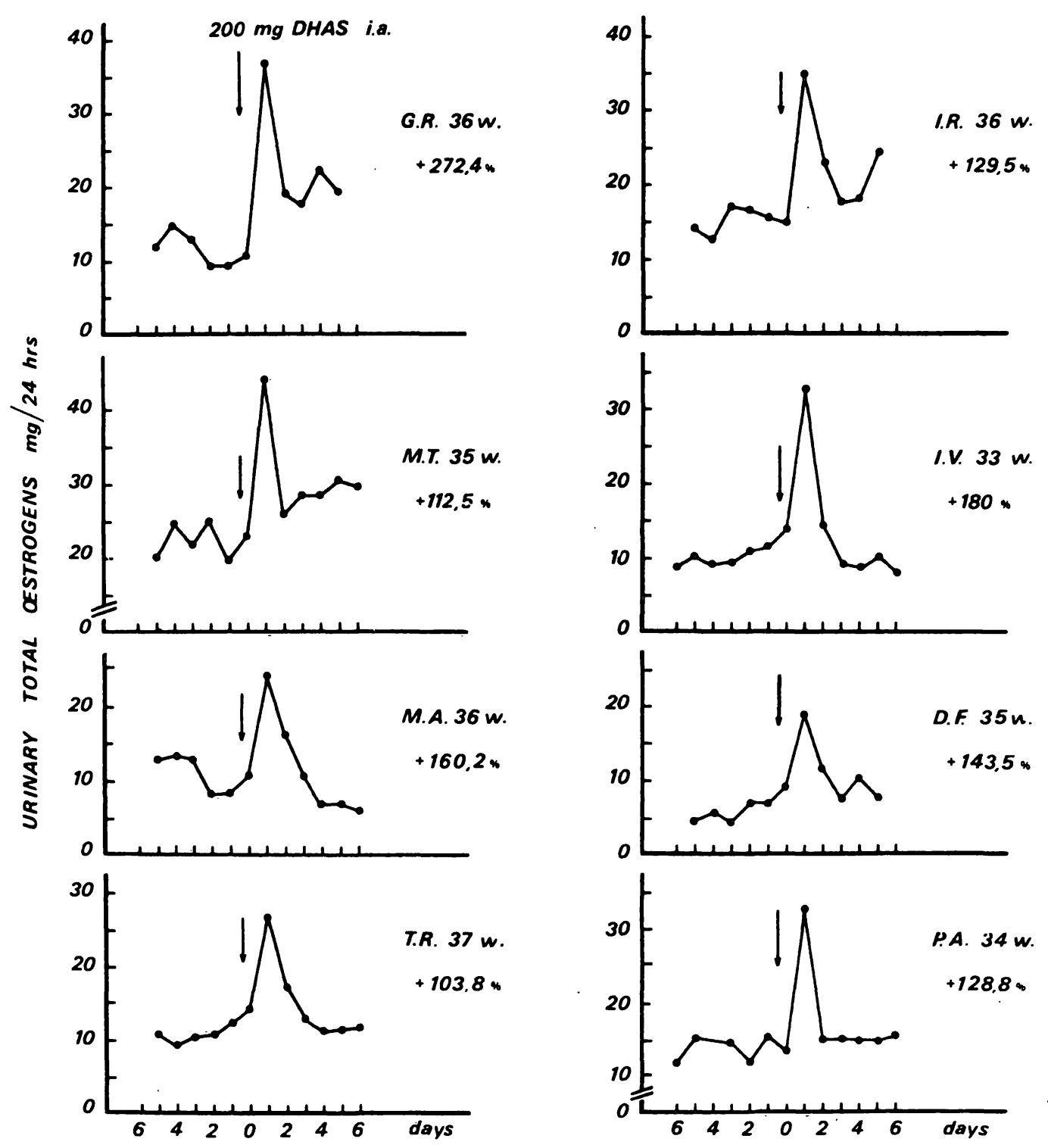

Fig. 1. Total urinary estrogens excretion in 8 cases of normal pregnancies before and after intraamniotic administration of dehydroepiandrosterone sulphate.

The results obtained confirm this assumption: LAURITZEN [6], who first used DHEA-S intravenous administration to the mother to test the steroid-metabolizing capacity of the fetoplacental unit, obtains a much lower increase of urinary estrogens.

Even when very high doses of DHEA-S (500 mg) are administrated intravenously to the mother, the increase of urinary estrogens is lower than that obtained by us [4].

By using intraamniotic administration a more significant correlation between the percentage of the increase and the functional condition of the steroid-synthetizing enzymatic complex can be established.

We introduce in the amniotic compartment the rather high dose of $200 \mathrm{mg}$ DHEA-S to be sure that the enzymatic complex was completely saturated.

It was found that normal pregnant women exhibit an average increase of $147.6 \pm 46,6$ S.D., in any case exceeding $100 \%$.

We can assume this limit as an indication of a good functional reserve of the enzymatic complex. 


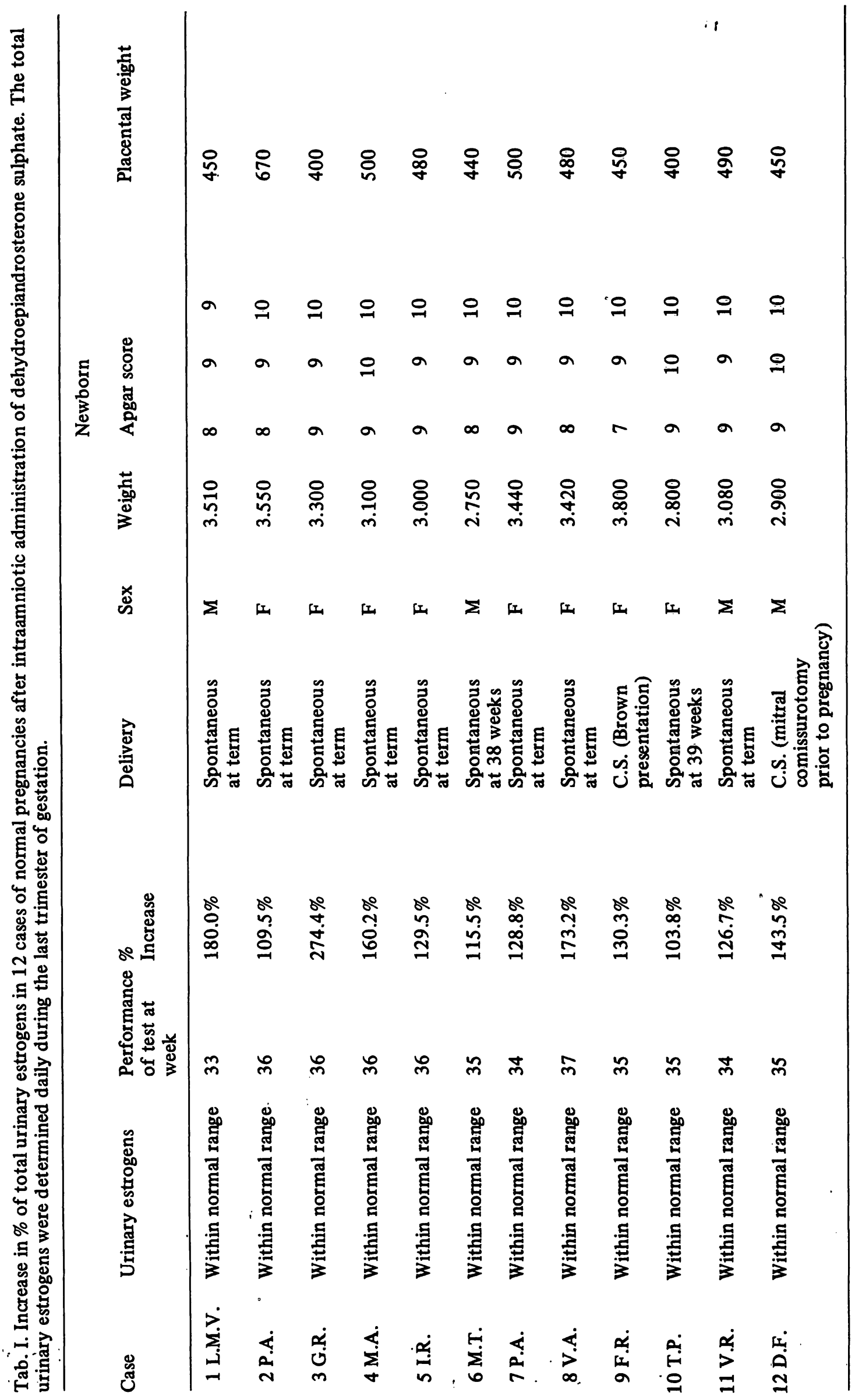



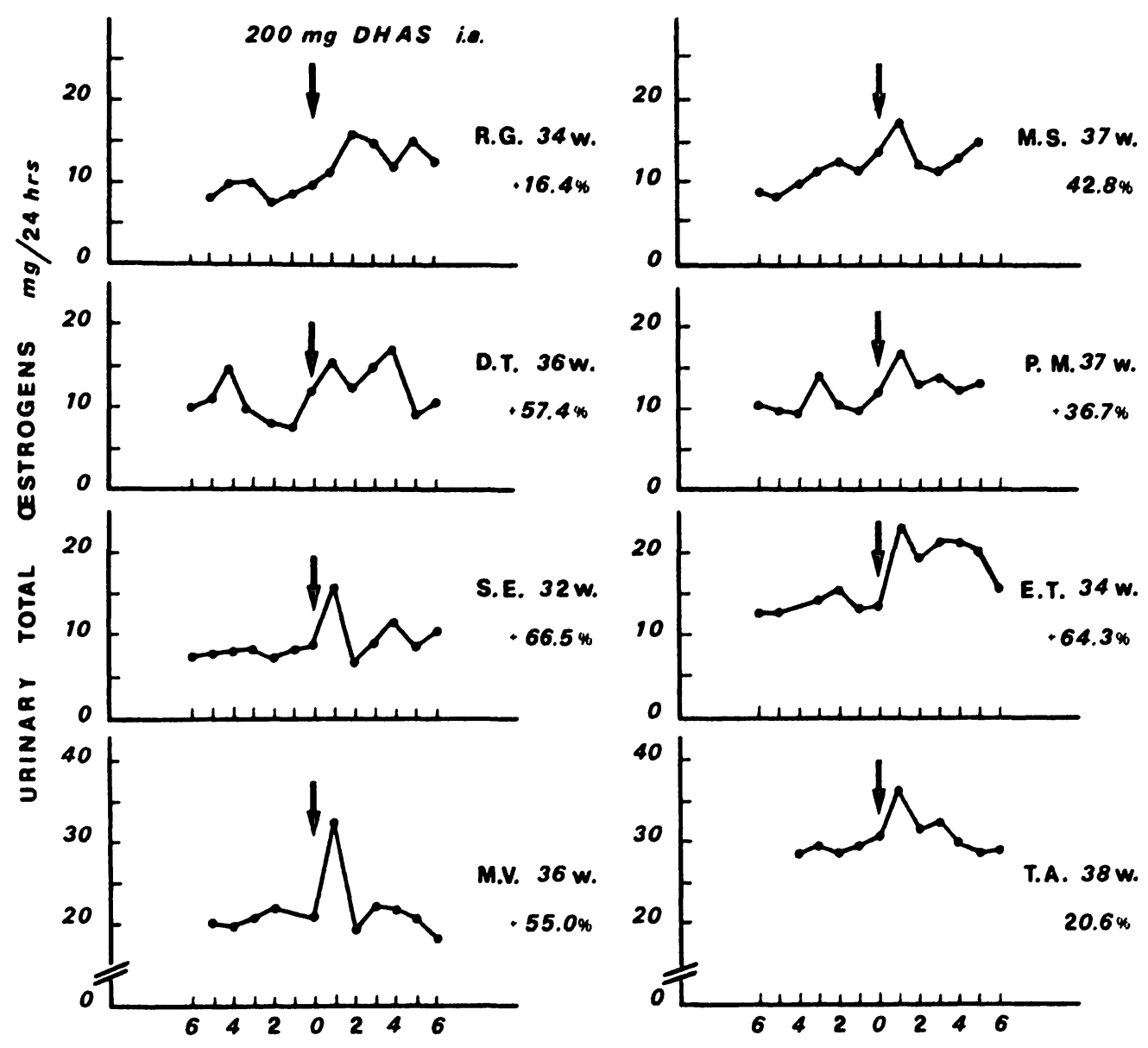

Fig. 2. Total urinary estrogens excretion in 8 cases of pathological pregnancies before and after intraamniotic administration of dehydroepiandrosterone sulphate.

On the other hand the average increase of pathological pregnancy with primary or secondary placental insufficiency was $48.6 \% \pm 19.2$ S.D.

From a clinical standpoint too it is interesting to determine whether injected DHEA-S is metabolized mainly by the placenta, or by the feto-placental unit.

JEFFERY et al. [4] have shown that the estriol/ estrone+estradiol ratio in maternal urine after intravenous administration of DHEA-S to the mother is much lower during estrogens increment than before DHEA-S administration and concluded that this precursor is metabolized mainly by the placenta, rather than by the feto-placental unit.

Some conclusions were reached by LAURITZEN [8], who administered tritiated DHEA-S intravenously to 6 pregnant women at term shortly before delivery and measured the distribution of labelled steroids in fetal umbilical vein and arteries, in the amniotic fluid as well as in maternal venous blood and urines at $10-20$ and $30 \mathrm{~min}$. following injection.

Only $20 \%$ of the DHEA.S injected goes to the fetus. The bulk is converted by the placenta to estrone and estradiol: estrone is the most important estrogenic metabolite excreted in the urine.

MANGO et al. [10] reached a similar conclusion after careful investigation of the metabolic fate of $200 \mathrm{mg}$ of DHEA-S injected into the amniotic compartment, with the determination in maternal urines of estriol, estradiol, estrone, DHEA, etiocholanolone and androsterone, before and after DHEA-S injection.

Different results were obtained by LEHMANN and STRECKER, who injected a mixture of cold DHEA and radioactive DHEA-S into the amniotic 

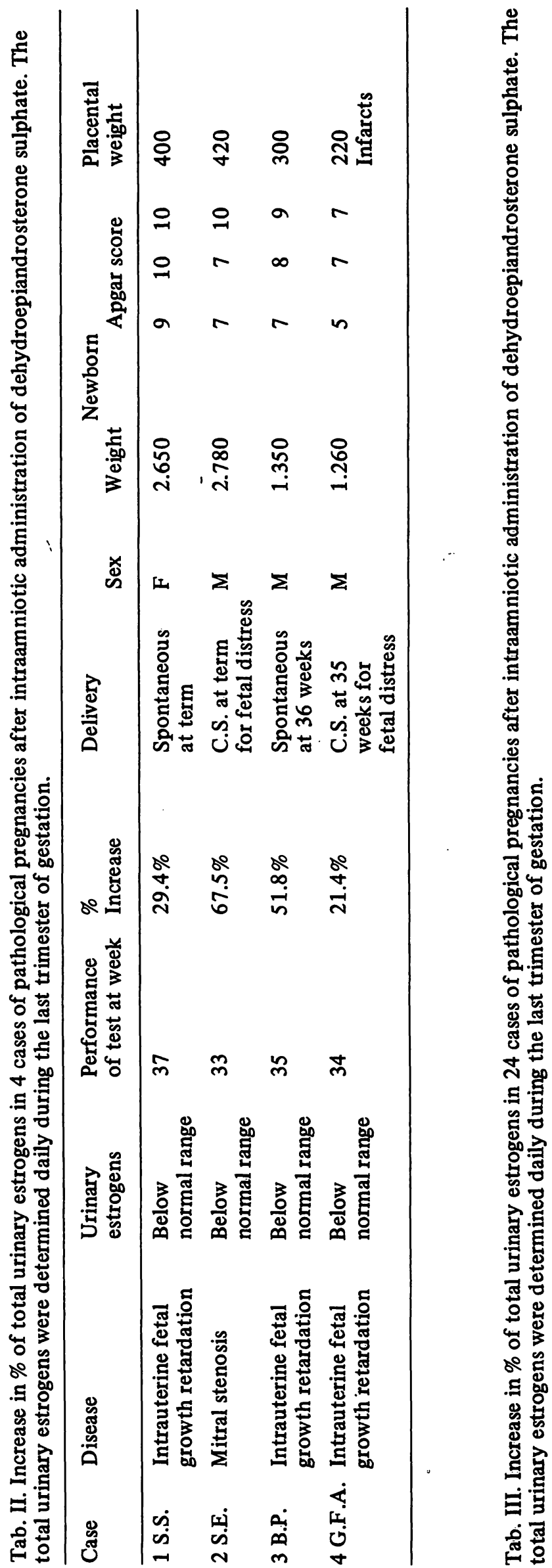

焉震

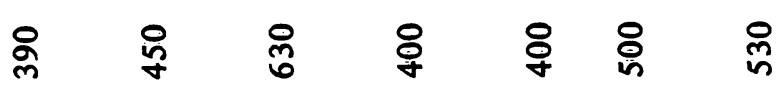

$\mid \begin{array}{lllllll}0 & 0 & a & a & 0 & 0 & 0 \\ a & a & a & \infty & a & a & 0\end{array}$

팡

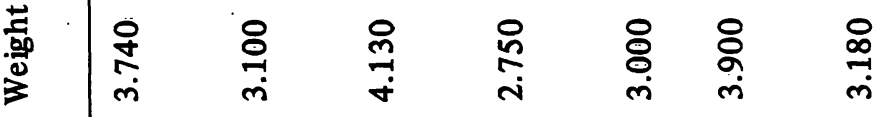

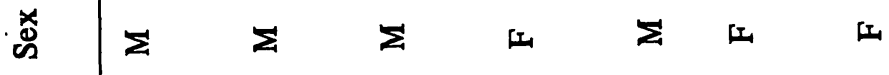

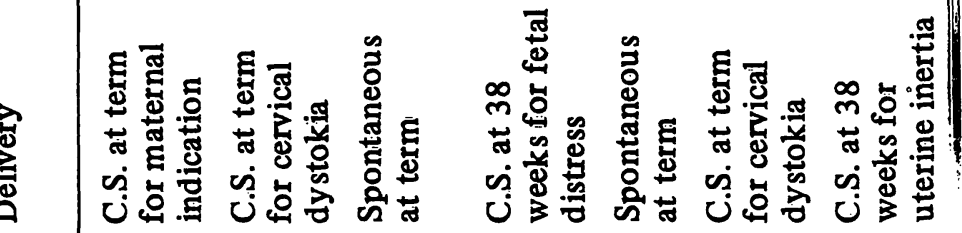

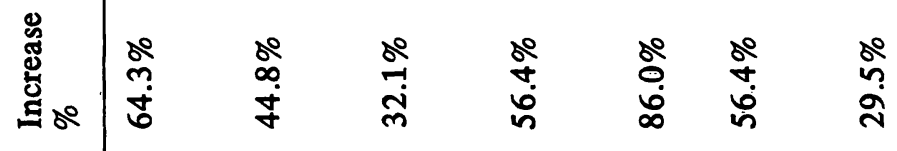

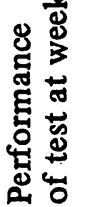

मे

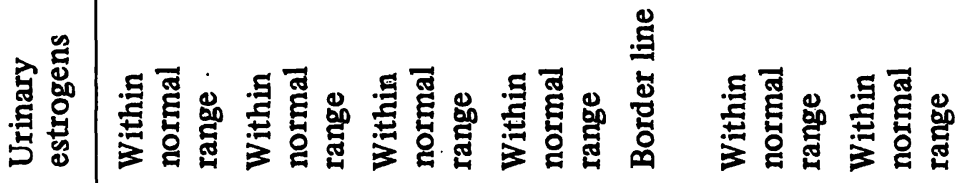

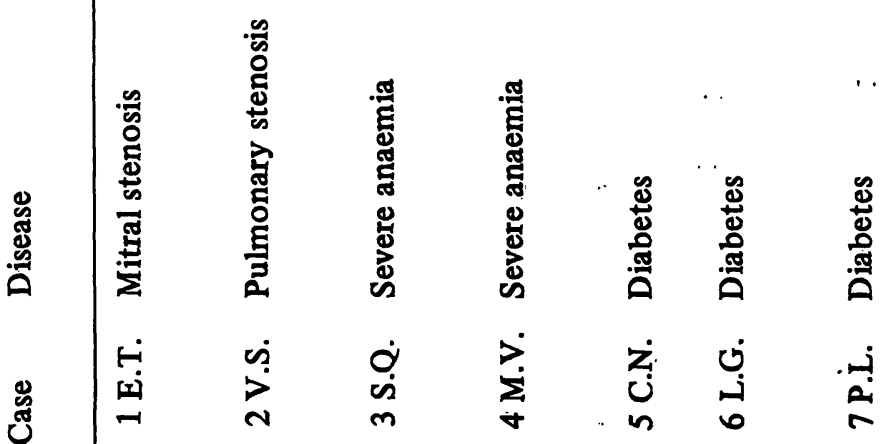




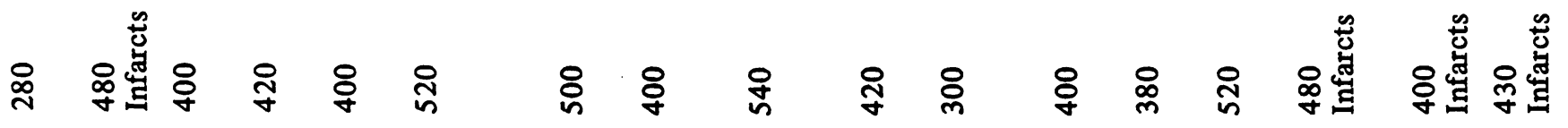

\begin{tabular}{|c|c|c|c|c|c|c|c|c|c|c|c|c|c|c|}
\hline$r$ & $\infty$ & $\stackrel{ }{\ominus}$ & $\stackrel{ }{-1}$ & a & $\infty$ & $a$ & $a$ & $\stackrel{0}{-1}$ & $a$ & $\stackrel{0}{=}$ & $a$ & $\stackrel{\varrho}{\varrho}$ & a & a \\
\hline$n$ & $\infty$ & $\stackrel{0}{\sigma}$ & $a$ & $r$ & $N$ & $\infty$ & . & $a$ & $a$ & $a$ & a & $\stackrel{0}{\longrightarrow}$ & $\infty$ & $\infty$ \\
\hline$N$ & $N$ & a & $a$ & 6 & 6 & $r$ & $\infty$ & $\infty$ & $\infty$ & $\infty$ & $\infty$ & $a$ & $N$ & $\infty$ \\
\hline
\end{tabular}

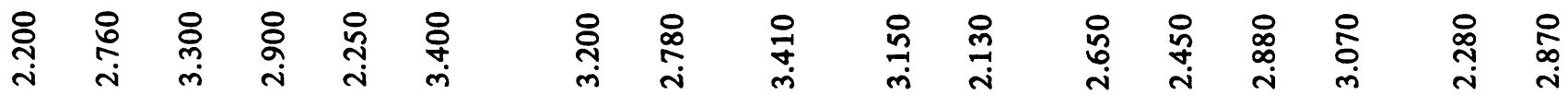

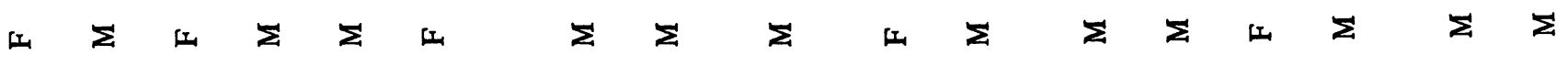

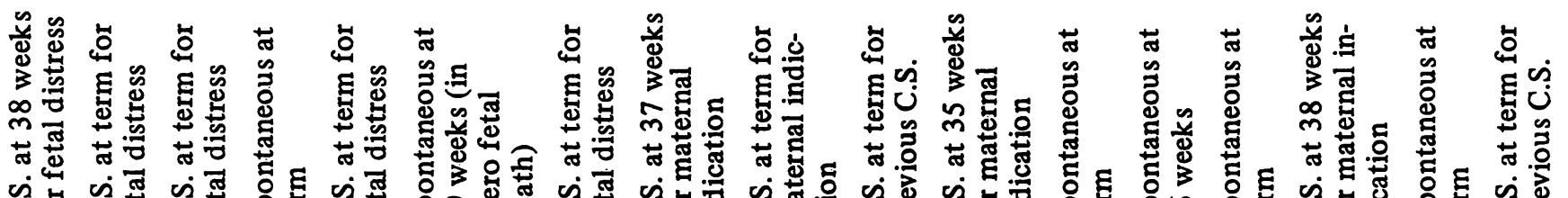

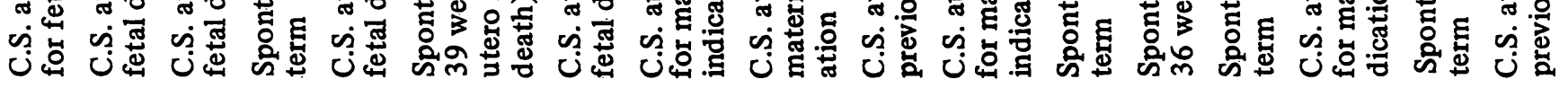

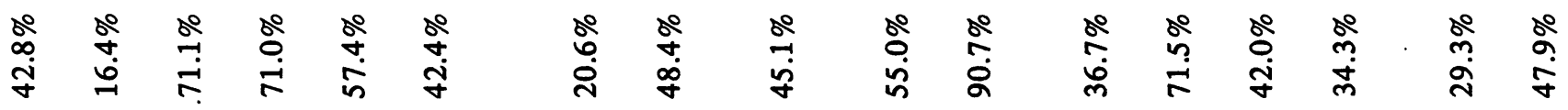

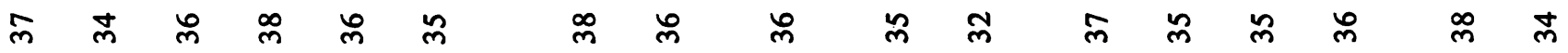

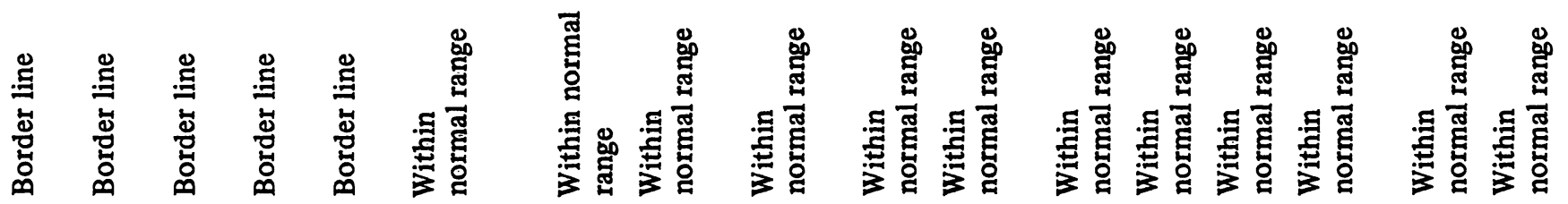

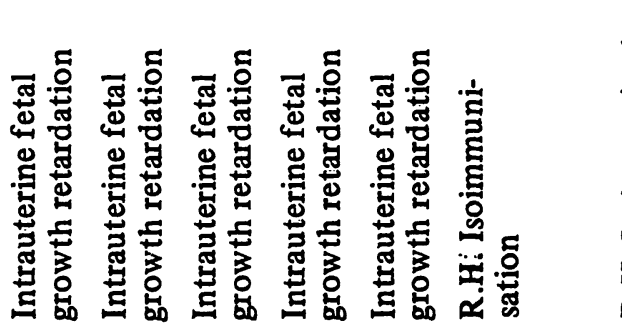

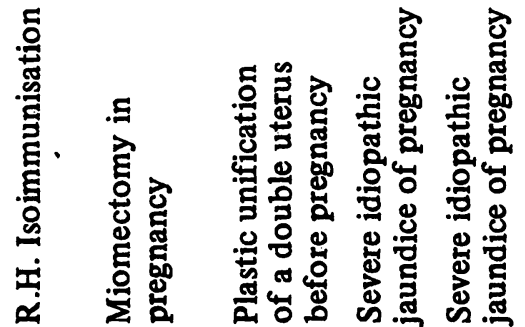

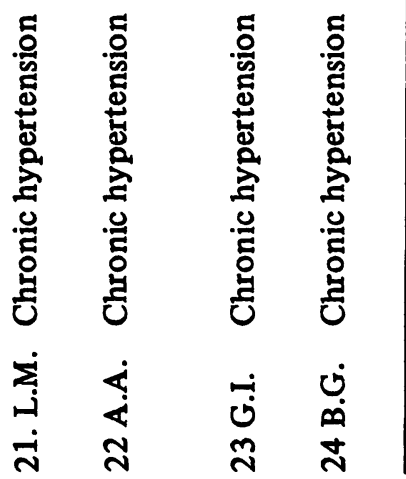

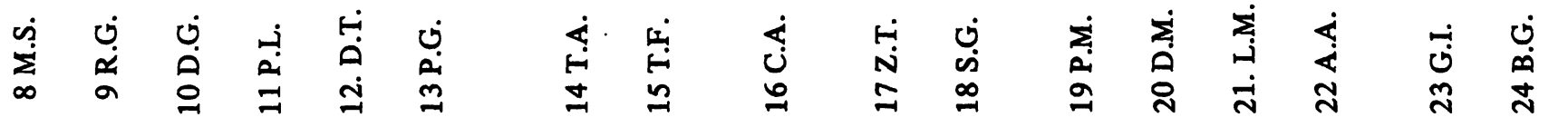




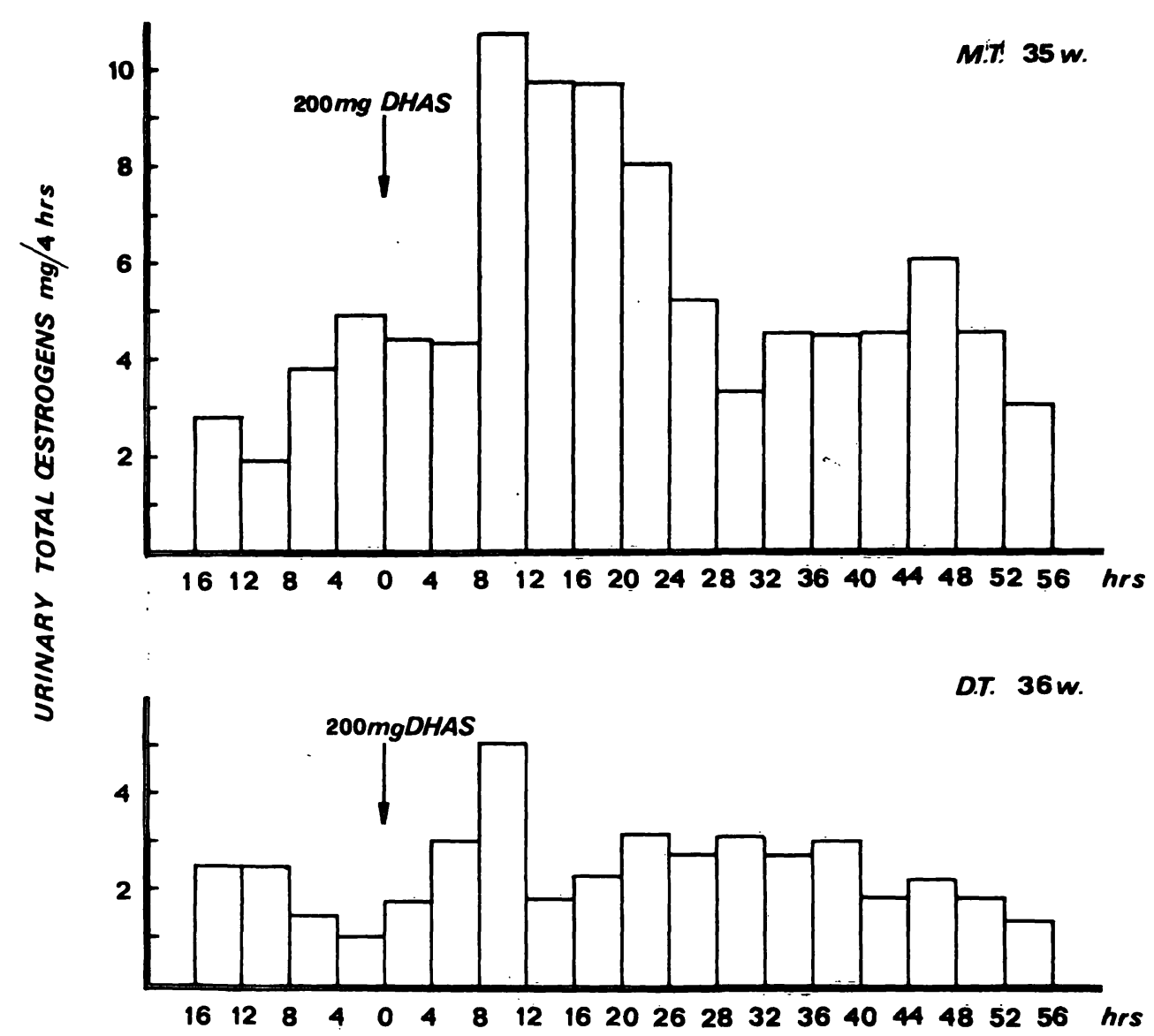

Fig. 3. Two profiles of urinary assays of total estrogens, performed every $4 \mathrm{hrs,} \mathrm{in} \mathrm{two} \mathrm{cases,} \mathrm{one} \mathrm{normal} \mathrm{and} \mathrm{one}$ pathological, before and after intraamniotic administration of dehydroepiandrosterone sulphate.

cavity, but in different experimental conditions (at 20 th week of gestation, $5 \mathrm{mg}$ of DHEA).

They found that estriol was the most important radioactive $\mathrm{C}_{18}$ steroid that rise in the maternal circulation [9].

The high increment of urinary estrogens after DHEA-S administration in the cases illustrated in Tab. IV could be explained by the fact that in these patients the fetus synthetized insufficient quantities of DHEA-S, whereas the placental function was normal.

In many pathological cases (Tab. III) the results demonstrated that the predictive values of the intraamniotic DHEA-S test can improve those obtained by the simple urinary estrogen assay. These findings agreed with those obtained by LAURITZen [8], Stembera and HerżmanN [13], Keller [5], VAN DER CRABbEN et al. [2], by injecting DHEA-S intravenously to the mother.

In conclusion we consider the intraamniotic DHEA$S$ test very reliable and maybe more significant than the analogous maternal intravenous DHEA-S test.

It can be used in the case of pregnancies at risk where the urinary estrogen values are questionable, particularly when a pathological pregnancy is suspected, but the urinary estrogens values are within the normal range.

\section{Summary}

It is well know that in pregnancy dehydroepiandrosterone-sulphate (DHEAS) $(90 \%$ synthetized by the fetal adrenals, $10 \%$ by the maternal ones) is converted into estrogens mainly in the placenta.

In order to evaluate the steroid metabolizing capacity of the placental enzymatic complex under load conditions,

a test was devised based upon a rapid introduction of $200 \mathrm{mg}$ of DHEAS into the amniotic compartment during the third trimester of gestation.

The purpose of the present investigation was to establish the clinical utility of such a test in comparison with the simple urinary estrogen determination test. 


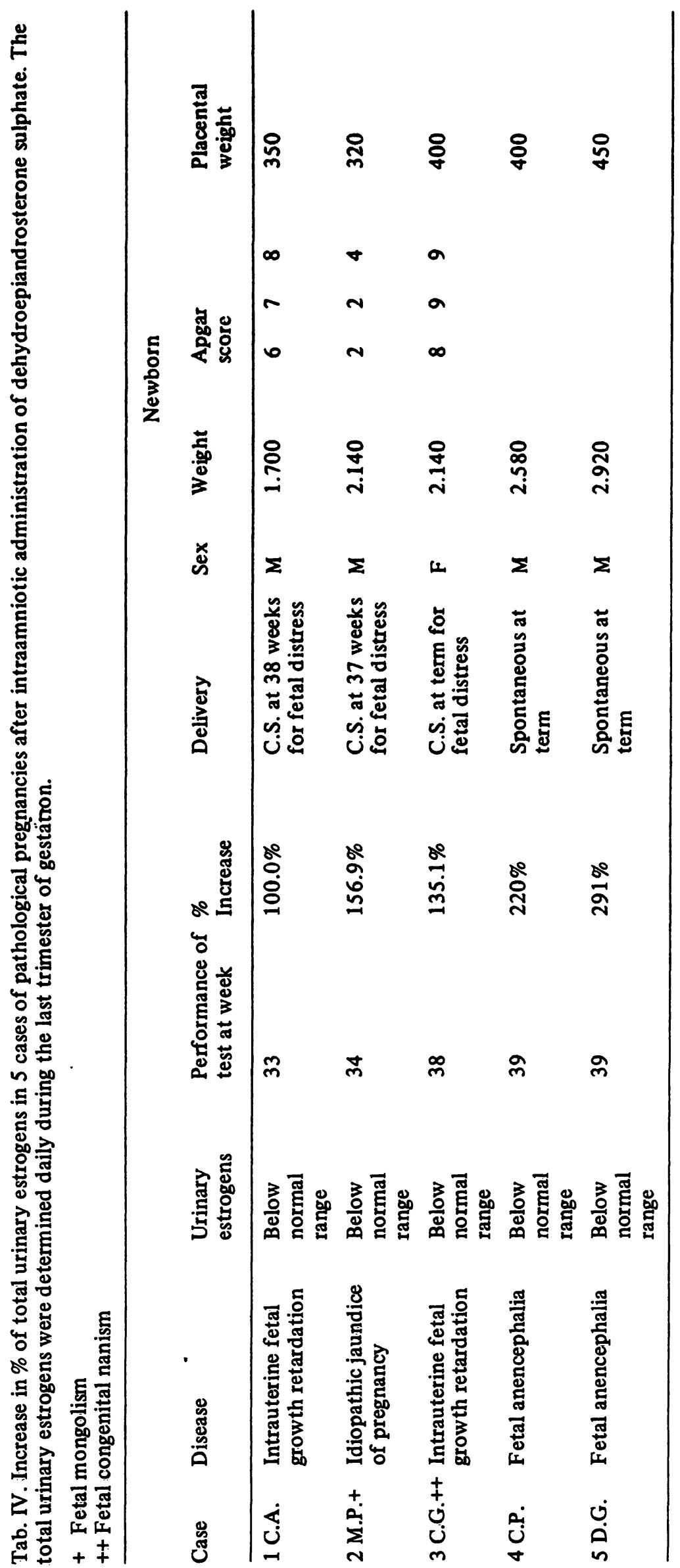


After DHEAS administration an increment in maternal urinary excretion of total estrogens was obtained: this increment over the $24 \mathrm{hrs}$ following the DHEA-S injection was assessed as the percentage of the mean of the two 24 hrs excretion values before DHEA-S administration.

The test was performed in 45 pregnancies (12 normal, 33 pathological). In all the normal pregnancies an increment of total urinary estrogens in the first $24 \mathrm{hrs}$ urine exceeding $100 \%$ was obtained, with an average of $147,6 \% \pm$ 46,6 S.D. (Fig. 1).

Conventionally, an increment exceeding $100 \%$ was considered an indication of normality. In these 12 cases the values of the daily urinary estrogens determinations were within the normal range (Tab. I). In 4 of the cases of pathological pregnancies considered, both daily urinary estrogens excretion and estrogens increment after DHEA$\mathrm{S}$ administration were below the normal range (Tab. II).

In 24 cases the daily urinary estrogens excretion was within the normal range or at border line, but the in- crement after DHEA-S administration never reached $100 \%$ (Tab. III).

The last 5 cases presented low daily urinary estrogens excretion, but a normal increment after DHEA-S administration (Tab. IV).

This group collected cases of fetal pathology, in which the synthesis of DHEA-S by the fetal adrenals was probably insufficient, whereas the placental function was normal.

In conclusion we consider the intraamniotic DHEA-S test very reliable and maybe more significant than the analogous maternal intravenous DHEA-S test, because utilizing the intraamniotic administration it is possible to obtain a higher increment in estrogens synthetised by the placenta and excreted in maternal urines.

It can be used in the case of pregnancies at risk, where the urinary estrogens values are questionable, particulary where there is suspicion of fetal distress, but the urinary estrogens values are within the normal range.

'Keywords: Dehydroepiandrosterone sulphate, feto-placental function, injection intraamniotic.

\section{Zusammenfassung}

Bestimmung der feto-plazentaren Funktion durch intraamniale Gabe von Dehydroepiandrosteron-Sulfat

Es ist bekannt, daß Dehydroepiandrosteron-Sulfat (DHEAS), von dem $90 \%$ in der fetalen und $10 \%$ in der mütterlichen Nebenniere synthetisiert wird, während der Schwangerschaft hauptsächlich in der Plazenta in Östrogene umgewandelt wird. Um die Fähigkeit des plazentaren Enzymapparates für den Steroidstoffwechsel bei Belastung zu bestimmen, wurde ein Test angewendet, der auf einer raschen Injektion von $200 \mathrm{mg}$ DHEA-S in das Fruchtwasser während des letzten Drittels der Schwangerschaft beruht. Das Ziel der vorliegenden Untersuchung war dabei, die klinische Brauchbarkeit eines solchen Tests im Vergleich mit der herkömmlichen Östrogenbestimmung im Urin aufzuzeigen.

Nach DHEA-S-Injektion wurde ein Anstieg der Gesamtöstrogene im Urin beobachtet. Die Zunahme, die während der nächsten 24 Stunden nach DHEA-S-Gabe erfolgte, ließ sich als prozentualer Anstieg gegenüber dem Mittel von 2 Gesamtöstrogenbestimmungen in den 24 Stunden vor der DHEA-S-Injektion berechnen. Der Test wurde bei 45 Schwangeren durchgeführt (12 normale und 33 pathologische Schwangerschaften). Bei allen normalen Schwangerschaften betrug der Anstieg der Gesamtöstrogene im ersten 24-Stunden-Urin über $100 \%$. Die Zunahme lag im Mittel bei $147,6 \%$ mit einer Standardabweichung von $\pm 46,6$ (Fig. 1). Gewöhnlich bedeutet ein Anstieg, der über $100 \%$ liegt, daß eine normale Funktion vorhanden ist. Auch die Östrogenausscheidung war bei diesen 12 Fällen innerhalb der Norm (Tab. I). In 4 Schwangerschaften, die als pathologisch eingestuft waren, lag sowohl die Östrogenausscheidung wie auch der Anstieg nach DHEA-S-Gabe unterhalb der Norm (Tab. II). Bei 24 der untersuchten Fälle zeigte sich, daß die Gesamtöstrogenbestimmung im Urin normale Werte oder Grenzwerte lieferte, die Zunahme nach DHEA-S-Injektion jedoch in keinem Fall $100 \%$ erreichte (Tab. III). In den 5 übrigen Schwangerschaften waren die Gesamtöstrogenwerte im Urin niedrig, während aber nach DHEA-S-Gabe ein normaler Anstieg gemessen werden konnte (Tab. IV). Diese Gruppe faßt Fälle zusammen, in denen die DHEA-SSynthese durch die fetale Nebenniere möglicherweise zu gering war, wohingegen die Plazentafunktion als normal anzusehen ist.

Abschließend kann gesagt werden, daß ein Belastungstest, der auf einer intraamnialen DHEA-S-Gabe beruht, eine gute und möglicherweise bedeutsamere Aussage liefert als der analoge Test nach intravenöser Applikation von DHEA-S an die Mutter. Nach intraamnialer Verabreichung kann man einen höheren Anstieg der von der Plazenta synthetisierten und im mütterlichen Urin ausgeschiedenen Östrogene beobachten.

Der Test sollte bei Risikoschwangerschaften eingesetzt werden, in denen unsichere Östrogenwerte im Urin vorliegen und insbesondere in Fällen, wo der Verdacht einer fetalen Gefährdung besteht, die Östrogenausscheidung aber normal ist. 


\section{Résumé}

Evaluation de la fonction foeto-placentaire par l.administration intra-amniotique de dehydroepiandrosteronesulphate

Il est bien connu que, dans la grossesse, le dehydroepiandrosterone-sulphate (DHEAS) (90\% synthétisés par les glandes surrénales du foetus, $10 \%$ par celles de la mère) se transforme en oestrogènes principalement dans le placenta.

Afin d'évaluer la capacité métabolisante de stéroide du complexe enzymatique placentaire sous les conditions de charge, un test a été établi, basé sur une introduction rapide de $200 \mathrm{mg}$ de DHEAS dans le compartiment amniotique pendant le troisième trimestre de gestation.

Le but de l'investigation présente a été d'établir l'utilité clinique d'un tel test en comparaison avec le simple test de détermination d'oestrogène dans l'urine. A la suite de l'administration de DHEA-S, on a obtenu un incrément de l'excrétion urinaire maternelle des oestrogènes totals: cet incrément des $24 \mathrm{~h}$. consécutives à l'injection de DHEA-S a été évalué comme le pourcentage de la moyenne des deux valeurs d'excrétion de $24 \mathrm{~h}$. avant l'administration de DHEA-S.

Le test a été effectué dans $\mathbf{4 5}$ grossesses (12 normales, 33 pathologiques). Dans toutes les grossesses normales, on a obtenu un incrément d'oestrogènes urinaires complets dans les urines des premières $24 \mathrm{~h}$. excédant $100 \%$, avec une moyenne de $147,6 \% \pm 46,6$ S.D. (Fig' 1).

On avait convenu qu'un incrément dépassant $100 \%$ pouvait être considéré comme normal. Dans ces 12 cas, les valeurs des déterminations d'oestrogènes dans les urines quotidiennes sont restées dans les limites normales (Tab. I)! Dans 4 des cas de grossesse pathologique, l'excrétion d'oestrogènes des urines quotidiennes et l'incrément d'oestrogènes après administration de DHEA-S ont été inférieurs à la normale (Tab. II).

Dans 24 cas, l'excrétion d'oestrogènes des urines quotidiennes a été normale ou à la limite des normes, mais l'incrément après administration de DHEA-S n'a jamais atteint $100 \%$ (Tab. III).

Les 5 derniers cas ont présenté une excrétion basse d'oestrogènes des urines quotidiennes, mais un incrément normal après administration de DHEA-S (Tab. IV).

Ce groupe a rassemblé des cas de pathologie foetale où la synthèse de DHEA-S par les glandes surrénales du foetus a été probablement insuffisante, tandis que la fonction placentaire était normale.

En conclusion, nous considérons que le test de DHEA-S intraamniotique présente un degré d'infaillibilité très élevé et peut être plus significatif que le test de DHEA-S intraveineux maternel analogique parce qu'ayant recours à l'administration intra-amniotique, on peut obtenir un incrément plus élevé d'oestrogènes synthétisés par le placenta et excrétés dans les urines maternelles.

Le test peut être utilisé dans les cas de grossesses à risque où les valeurs d'oestrogènes de l'urine restent contestables, particulièrement quand on suspecte un distress foetal, bien que les valeurs d'oestrogènes de l'urine se situent dans les limites normales.

Mots-clés: dehydroepiandrosterone-sulphate, fonction foetoplacentaire, intra-amniotique.

\section{Bibliography}

[1] BROWN, J. B., N. A. BEISHER, M. A. SMITH: Excretion of urinary estrogens in pregnant patients treated with cortisone and its analogues. J. Obstet. Gynaec. Brit. Comm. 75 (1968) 819

[2] CRABBEN VAN DER, H., K. HAMMACHER, CH. WERNER, KAISER, E.: Die Beurteilung der Plazentafunktion durch DHEA-S Belastung im Vergleich zur Kardiotokographie und Plazentahistologie. Geburtsh. Frauenheilk. 30 (1970) 71

[3] DICZFALUSY, E.: Steroid metabolism in the fetoplacental unit. In: PECILE, FINZI: The feto-placental unit. Proceedings of International Simposium held in Milan, Italy. Excerpta Medica, Amsterdam, ICS 183 (1969) 65

[4] JEFFERY, J., G. M. SWAPP, G. R.'WILSON, K. FOTHERBY: Effect of adrenocorticotrophic hormon and androst-5-en-17- on-3 yl-sulphate administration to the mother on urinary estrogen excretion in late human pregnancy. J. Endocr. 48 (1970) 591

[5] KELLER, P. J.: Hormonale und enzymologische Methoden zur Diagnose der Plazentainsuffizienz bei EPH-Gestose. In: RIPPMANN, E. T., CH. RIPPERT:
EPH Gestosis. Diagnose und Resultate. Walter de Gruyter, Berlin-New York 1972

[6] LAURITZEN, CH.: A clinical test for placental functional activity, using DHEA-Sulphate. Acta Endocr. 119 (1967) 88

[7] LAURITZEN, CH.: Bedeutung der Ostrogenbestimmung und des Dehydroepiandrosteron-Test in der Beurteilung und Behandlung von Risikoschwangerschaften. In: DUDENHAUSEN, J.W., E. SALING: Perinatale Medizin, Bd. II. Thieme, Stuttgart 1972

[8] LAURITZEN, CH.: Dynamic tests of feto-placental function and endocrine therapy. In: SCHOLLER, R., E. SEPE (eds): Hormonal investigations in human pregnancy. Paris, 1974

[9] LEHMANN, W. D., J. R. STRECKER: Estrogens in maternal plasma following intraamniotic injection of $\left({ }^{3} \mathrm{H}\right)$-dehydroepiandrosterone-sulphate in midpregnancy. J. Perinat. Med. 4 (1976) 255

[10] MANGO, D., P. SCIRPA, E. MENINI: Destino metabolico del Deidroepiandrosterone solfato iniettato nel liquido amniotico nel corso del III trimestre di gravidanza. Acta Medica Romana 12 (1974) 155 
[11] MENINI, E., A. BOMPIANI: Automatione nella clinica analitica. Simposio Internazionale Technicon. Roma 1969

[12] MONETA, E., G. GALlI, L. TRONCONE, N. GARCEA: La scintigrafia della placenta con Indio radioattivo. Aspetti clinico-biologici. Min. Ginecologica 22 (1970) 48
[13] STEMBERA, Z. K., J. HÉRZMANN: Estriol-Untersuchung nach DHEA-S als Test für plazentare Insuffizienz, Cslka, Gyneak. 26 (1971) 597

Received November 11, 1977. Revised January 7, 1979. Accepted January 23, 1979.

\section{Prof. Sergio Dell'Acqua \\ Istituto di Clinica Ostetrica e Ginecologica \\ Policlinico Agostino Gemelli \\ Università Cattolica del Sacro Cuore \\ Largo Gemelli, 8 \\ ROMA/Italy}

